\title{
The health effects of climate change: Know the risks and become part of the solutions
}

\author{
C Howard ${ }^{1,2 *}$, P Huston ${ }^{3}$
}

\begin{abstract}
Climate change presents a clear and present danger to human health. Health impacts are already being demonstrated in Canada, which is warming at roughly twice the global rate. A recent United Nations Environment Emissions Gap Report noted that if countries maintain current emission efforts, emissions will exceed the targets laid out in the Paris Agreement and global warming will exceed $2^{\circ} \mathrm{C}$ worldwide. An important consequence of global warming is an increase in health risks. Much can be done to prevent and mitigate the health impacts of climate change, and understanding and communicating these has been shown to be one of the best ways of motivating action. This editorial provides an overview of the some of the global and national initiatives underway to decrease emissions, and address the health risks of climate change in general, and highlights some of the national initiatives underway to mitigate the increased risk of infectious diseases in Canada in particular.
\end{abstract}

Suggested citation: Howard C, Huston P. The health effects of climate change: Know the risks and become part of the solutions. Can Commun Dis Rep 2019;45(5):114-8. https://doi.org/10.14745/ccdr.v45i05a01

Keywords: climate change, health impact, infectious diseases, resilience, adaptation, prevention, emissions, eco-anxiety, ecological grief, mosquito-borne diseases, surveillance
This work is licensed under a Creative Commons Attribution 4.0 International License.

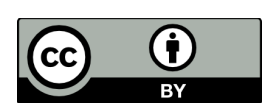

Affiliations

${ }^{1}$ Northwest Territories Health and Social Services Authority, NWT, Canada

${ }^{2}$ Canadian Association of Physicians for the Environment, Toronto, ON

${ }^{3}$ Infection Prevention and Control Branch, Public Health Agency of Canada, Ottawa, ON

${ }^{\star}$ Correspondence:

courtghoward@gmail.com

\section{Introduction}

The World Health Organization has stated that "Climate change is the greatest challenge of the $21^{\text {st }}$ century, threatening all aspects of the society in which we live" (1). To address this challenge, 175 countries have ratified the Paris Agreement within the United Nations Framework Convention on Climate Change (2). Collectively, these countries agreed to limit global average temperature rise to well below $2^{\circ} \mathrm{C}$, and to pursue efforts to limit the increase to $1.5^{\circ} \mathrm{C}$. Canada is a signatory to the Paris Agreement and has committed to cut emissions to $30 \%$ below 2005 levels by 2030 . Unfortunately, in 2016 Canada's emissions had actually increased compared with 1990 (3). Although some countries have made great progress (notably, the United Kingdom and China), the 2018 United Nations Environment Emissions Gap Report noted that if all signatory countries maintain current emission efforts, emissions will exceed the targets laid out in the Paris Agreement, and global warming will exceed $2^{\circ} \mathrm{C}(4)$.

To respond to the need to reduce emissions and build climate resilience, the Government of Canada, after extensive consultations with provinces, territories and Indigenous Peoples, developed a national climate change plan. The Pan-Canadian Framework on Clean Growth and Climate Change was adopted by most of the Canadian First Ministers in December 2016 (5). The Framework notes the science is clear: human activities are driving unprecedented changes in the Earth's climate, which pose significant risks to communities, human health, security, economic growth and the natural environment. It notes that the impacts of climate change are already evident in that there is already documented coastal erosion, thawing permafrost, the arrival of diseases that had previously been contained to warmer climates, increases in heat waves, droughts and flooding as well as risks to critical infrastructure and food security (5). The plan to address this in Canada was developed around four pillars: pricing carbon pollution; complementary actions to reduce emissions across all sectors; adaptation and resilience; and clean technology, innovation and jobs. The Framework includes more than fifty concrete actions and positions by which Canada aims to meet its Paris Agreement greenhouse gas emissions reduction target by 2030. For example, carbon pollution pricing systems and benchmarks have been established across Canada.

Although annual reports on this Pan-Canadian Framework have documented important progress (6), there is still a gap between where we are and where we need to be so that Canada can meet its targets. The recent 2019 Canada's Changing Climate Report, produced by Environment and Climate Change Canada, noted that Canada is currently warming at twice the mean global rate, with the Canadian Arctic warming, on average, at triple the global rate (7). For example, the McKenzie Delta region is already $3^{\circ} \mathrm{C}$ warmer than in the 1950 s (8). 


\section{The health effects of climate change}

Meeting our emission commitments is not a theoretical "nice to have". There is a growing awareness that climate change is leading to emerging health threats. Internationally, efforts such as the Lancet Countdown on Health and Climate Change, have made clear that some of the top health threats worldwide include heat-related adverse effects on health and work productivity, worsening markers of food security, and intensifying infectious disease impacts.

There is growing evidence of climate-related health threats in Canada. With rising temperatures in the north, landbased food security has been threatened for Indigenous populations $(9,10)$, the safety of ice-based travel has been reduced and mental health has been strained (11). Climaterelated health risks across Canada include increased heat stroke and death from the increased number and duration of heat waves (12,13); and respiratory impacts from wildfire-related air pollution (14). Extreme wildfires are expected to continue to increase (7), leading to episodes of severe air pollution and increased stresses on healthcare facilities and healthcare providers (as was seen during the emergency evacuation of the hospital in Fort McMurray in 2016). Similarly, floods are forecast to increase, bringing about their own risk of damage to property and the associated personal and societal disruption from evacuation. Anxiety and post-traumatic stress disordertype symptoms have been experienced by those who have been affected by fires, floods and extreme weather events (15). New terms, such as eco-anxiety and ecological grief are now entering the lexicon (16). Infectious disease risks of climate change in Canada were detailed in the April 2019 issue of Canada Communicable Disease Report, and included an increased risk of tick-borne diseases (17), endemic and exotic mosquito-borne diseases $(18,19)$, as well as foodborne diseases $(20)$.

Understanding the health impacts of climate change has been shown to be one of the best ways of motivating action (21), and health professionals and scientists are among the most trusted of messengers (22). In this editorial, we highlight some recent global and national initiatives to address both climate change and its health effects in general, and then highlight the work described in this issue on initiatives to address emerging infectious disease risks in particular.

\section{Global initiatives}

The recent Lancet Countdown on Health and Climate Change noted health professionals and health systems are increasingly considering and responding to the health effects of climate change (23). And for good reason: a better understanding of the health dimensions of climate change allows for advanced preparedness, increased resilience and adaptation and a prioritization of mitigation interventions that protect and promote human wellbeing (23).

The World Health Organization has been working on a new report entitled Global Strategy on Environment, Climate Change, and Health (24). The draft Global Strategy calls for an integrated approach for public health and environment science to intensify work on primary prevention and advance policies that address the root causes of environmental threats to health. The World Health Assembly is expected to approve this new strategy in May 2019.

Adaptation is about reducing the impacts associated with a given level of climate change. In October 2018, a new Global Commission on Adaptation was announced and is being led by former United Nations Secretary-General Ban Ki-moon, American businessman Bill Gates and World Bank Chief Executive Officer Kristalina Georgieva (25). The report will demonstrate why adapting to climate risks is essential, and will lay out the actions that are needed. The Commission will present its report at the United Nations Climate Summit in September 2019 in New York.

Globally, there is a youth movement calling for action on climate change, sparked by the 16-year old Swedish activist, Greta Thunberg (26). On March 15, 2019, 1.5 million youth, and their supporters in 123 countries, demonstrated around the world, demanding a significant response to climate change following an open letter to world leaders that stated: "You have failed us." (27), In Montreal alone, there were an estimated 150,000 demonstrators (28).

\section{Canadian initiatives}

The health effects of climate change in Canada have not gone unnoticed by healthcare professionals. In February 2019, the Canadian Medical Association, Canadian Nursing Association, Canadian Public Health Association, Canadian Association of Physicians for the Environment and the Urban Public Health Network issued a Call to Action, identifying climate change as a health emergency (29). The Canadian Federation of Medical Students and the International Federation of Medical Students' Associations have both called for climate-health to begin to be integrated into medical education by the end of 2020, with fuller integration by 2025 (30). Without it, health professionals may not be prepared for the climate-related health issues that they are bound to see currently in their practices and in the years ahead.

Canada is on track to phase out coal power by 2030; a policy that is expected to result in $\$ 1.3$ billion in health and environmental benefits from air quality improvement (31). Canada has now co-founded the Powering Past Coal Alliance with the United Kingdom in an effort to catalyze international efforts (32) that could multiply these health benefits. Equally, the new Food Guide for Canada, with its emphasis on a plantrich diet, is likely to result in a decrease in the greenhouse gas emissions that result from the production and consumption of animal-based foods. This is in line with the recommendations of the recent EAT-Lancet Commission that identifies benefits for both human and planetary health $(33,34)$. 
Much change is also possible at the community level. In terms of sustainable transportation, physicians and public health practitioners have become more active in encouraging active transport infrastructure in multiple communities to decreases emission rates and improve health (35). Vancouver's commitment to be one of the most sustainable cities in the world contains many elements that will increase activity levels and decrease air pollution (36). Getting people out of fossil fuel-powered cars and into more sustainable forms of transport, such as bicycles and buses, not only reduces emissions, it also reduces local air pollution, improves activity levels and reduces disease.

\section{Addressing the increased risk of infectious disease}

In this issue of the Canada Communicable Disease Report, you will read about how government and academic researchers in Canada have been finding solutions to address the increased risk of infectious diseases with climate change. A key focus has been early detection and prevention strategies. Rees et al. describe a new generation of surveillance strategies for the prediction and early detection of climate-related infectious disease outbreaks, namely risk modelling and event-based monitoring that uses open-source internet data, which has recently been refined by artificial intelligence applications, such as machine learning (37). Ogden et al. note that since warming, climate variability and extreme weather events drive the increase in the frequency and intensity of mosquito-borne diseases, understanding the associated weather patterns can provide early warning of when a region is at risk. Timely information on an impending outbreak can enable the implementation of mosquito control measures and risk communications-before an outbreak occurs (38). Kotchi et al. note that satellite images can provide data on indicators of environmental and climatic determinants that influence the presence and development of mosquito-borne and tick-borne diseases. Thus, data on change in temperature, humidity, ground cover and more can be used to predict infectious disease outbreaks. Work is now underway to increase predictability of this technique by using data from multiple satellites and applying innovative machine learning techniques to deal with big data (39). Germain et al. describe a new collaborative model among scientific experts and public policy makers across the province of Quebec in a "One World, One Health" organizational structure that provides a platform for knowledge-sharing, consensusbuilding and the development of adaptive strategies to address the increased risk of zoonotic diseases associated with climate change (40).

\section{Discussion and conclusion}

A December 2018 poll by Ipso Reid showed that the majority of Canadians agree that Canada needs to do more to address climate change (41). But awareness of the health effects of climate change is not yet widespread. It is important for all Canadians to know that climate change is increasingly affecting health in a number of ways. Health and public health providers have an important role to play in increasing the public awareness of these climate change-associated health risks. There is a positive message that can be imparted: a better understanding of the health effects of climate change enables increased preparedness, resilience, adaptation, and the development of strategies that protect and promote human health. And a lot of work is underway to address the health effects of climate change in the context of adaptation. These are focused on preparedness, prevention and resilience. It includes a whole new generation of strategies to detect when we are at increased risk of climateassociated infectious diseases.

Health and public health providers need to be ready to play an active role in the prevention, early detection and mitigation of the health effects of climate change. To do that, climate and health content needs to be increasingly included in curricula and in continuing education courses. The adverse effects of air pollution and the traumatic effects of extreme weather events are fairly obvious and well-documented. But the effects of climate change on emerging infectious disease risks in Canada are less evident and less well-known. In order not to miss climatechange induced emerging vector-borne diseases in affected people, a high index of suspicion and laboratory confirmation is needed. Understanding and staying abreast of the new strategies for the early detection of emerging disease risks and outbreaks that will likely be driven by a changing climate, will help health and public health professionals be prepared and respond.

Knowing the risks and being part of the solutions are healthy responses to climate change. There is a lot being done and a lot each healthcare professional can do to create a viable future for current and future generations. And that effort is worth it; to cultivate individual, family and community preparedness and resilience, to contribute to something larger than yourself-and because the world is watching.

\section{Authors' statement}

Both authors developed the overall conception and design of the editorial. PH developed the first draft and both $\mathrm{CH}$ and $\mathrm{PH}$ worked on subsequent drafts and revisions.

Dr. Courtney Howard is the President of the Canadian Association of Physicians for the Environment. Dr. Patricia Huston is the Editor-in-Chief of the Canada Communicable Disease Report and recused herself from taking any editorial decisions on this manuscript. Decisions were taken by the Guest Editor of the April 2019 issue, Dr. Nicholas Ogden.

\section{Conflict of interest}

None. 


\section{References}

1. Campbell-Lendrum D, Wheeler N, Maiero M, Villalobos Prats E, Nevelle T. World Health Organization COP24 Special Report on Health and Climate Change. World Health Organization; 2018. https://unfccc.int/sites/default/files/ resource/WHO\%20COP24\%20Special\%20Report_final.pdf

2. United Nations. Paris Agreement 2015. https://treaties. un.org/doc/Treaties/2016/02/20160215\%2006-03\%20PM/ Ch_XXVII-7-d.pdf

3. Government of Canada. Greenhouse Gas Emissions. 2018 (Accessed 2019-04-18). https://www.canada.ca/ en/environment-climate-change/services/environmentalindicators/greenhouse-gas-emissions.html

4. United Nations Environment Programme. Emissions Gap Report 2018. http://wedocs.unep.org/bitstream/ handle/20.500.11822/26895/EGR2018_FullReport_ EN.pdf?sequence $=1$ \&isAllowed $=y$

5. Government of Canada. Pan-Canadian Framework on Clean Growth and Climate Change. http://publications.gc.ca/ collections/collection_2017/eccc/En4-294-2016-eng.pdf

6. Environment and Climate Change Canada. Pan-Canadian Framework on Clean Growth and Climate Change: Second Annual Synthesis Report on the Status of Implementation December 2018. Government of Canada. http://publications. gc.ca/collections/collection_2018/eccc/En1-77-2018-eng.pdf

7. Bush E, Lemmen DS, editors. Canada's Changing Climate Report 2019; Government of Canada, Ottawa, ON. 444 p. https://www.nrcan.gc.ca/sites/www.nrcan.gc.ca/files/energy/ Climate-change/pdf/CCCR_FULLREPORT-EN-FINAL.pdf

8. Government of the Northwest Territories. Climate Observations in the Northwest Territories (1957-2012) Inuvik * Norman Wells * Yellowknife * Fort Smith. Environment and Natural Resources. https://www.enr.gov.nt.ca/sites/enr/files/ page_3_nwt-climate-observations_06-13-2015_vf_1_0.pdf

9. Rosol R, Powell-Hellyer S, Chan HM. Impacts of decline harvest of country food on nutrient intake among Inuit in Arctic Canada: impact of climate change and possible adaptation plan. Int J Circumpolar Health 2016 Jul;75(1):31127. DOl PubMed

10. Berry P, Clarke K, Fleury MD, Parker S. Human Health; in from Impacts to Adaptation: Canada in a Changing Climate. Government of Canada; 2014. P. 191-232. https://www. nrcan.gc.ca/sites/www.nrcan.gc.ca/files/earthsciences/pdf/ assess/2014/pdf/Chapter7-Human-Health_Eng.pdf

11. Cunsolo Willox A, Harper SL, Ford JD, Landman K, Houle K, Edge VL; Rigolet Inuit Community Government. "From this place and of this place:" climate change, sense of place, and health in Nunatsiavut, Canada. Soc Sci Med 2012 Aug;75(3):538-47. DOl PubMed

12. Dover GP, Gould R, Hayes J, Kenny G, Moore K, Mowat D, Nobbe S, Payne L, Petrucka P. Extreme Heat Events Guidelines: Technical Guide for Health Care Health Workers, 2018. 2018-08-07. Catalog No: H128-1/11-642E. https:// www.canada.ca/en/health-canada/services/environmental- workplace-health/reports-publications/climate-changehealth/extreme-heat-events-guidelines-technical-guidehealth-care-workers.html

13. Demers I, Gosselin P. Pollens, climate and allergies: Quebec initiatives. Health Promotion Chronic Disease Prevention in Canada 2019;39 (4) 136-41. DOI

14. Henderson SB, Johnston FH. Measures of forest fire smoke exposure and their associations with respiratory health outcomes. Curr Opin Allergy Clin Immunol 2012 Jun;12(3):221-7. DOl PubMed

15. Health A. Impact of Wildfires on the Mental Health of Fort McMurray Residents: Neurotic Disorders, Daily Physician Visits within an Emergency Department 2015 vs. 2016. Alberta Health, Health Standards, Quality and Performance Division, Analytics and Performance Reporting Branch, 2016.

16. Cunsolo A, Ellis N. Ecological grief as a mental health response to climate change-related loss. Nat Clim Chang 2018;8(4):275-81. DOI

17. Bouchard C, Dibernardo A, Koffi J, Wood H, Leighton PA, Lindsay LR. Increased risk of tick-borne diseases with climate and environmental changes. Can Commun Dis Rep 2019;45(4):83-9. DOI

18. Ludwig A, Zheng $H$, Vrbova L, Drebot MA, Iranpour $M$, Lindsay LR. Increased risk of endemic mosquito-borne diseases in Canada due to climate change. Can Commun Dis Rep 2019;45(4):91-7. DOI

19. Ng $V$, Rees EE, Lindsay LR, Drebot MA, Brownstone T, Sadeghieh T, Khan SU. Could exotic mosquito-borne diseases emerge in Canada with climate change? Can Commun Dis Rep 2019;45(4):98-107. DOI

20. Smith BA, Fazil A. How will climate change impact microbial foodborne disease in Canada? Can Commun Dis Rep 2019;45(4):108-13. DOI

21. Myers T, Nisbet M, Maibach E, Leiserowitz A. A public health frame arouses hopeful emotions about climate change. Clim Change 2012;113(3-4):1105-12. DOI

22. Firefighters and Nurses Top List of Canada's Most Trusted Professionals. March 15, 2018. Insights West. https:// insightswest.com/news/firefighters-and-nurses-top-list-ofcanadas-respected-professionals/

23. Watts N, Amann M, Arnell N, Ayeb-Karlsson S, Belesova K, Berry H, Bouley T, Boykoff M, Byass P, Cai W, Campbell-Lendrum D, Chambers J, Daly M, Dasandi N, Davies M, Depoux A, Dominguez-Salas P, Drummond $P$, Ebi KL, Ekins P, Montoya LF, Fischer H, Georgeson L, Grace D, Graham H, Hamilton I, Hartinger S, Hess J, Kelman I, Kiesewetter G, Kjellstrom T, Kniveton D, Lemke B, Liang L, Lott M, Lowe R, Sewe MO, Martinez-Urtaza J, Maslin M, McAllister L, Mikhaylov SJ, Milner J, Moradi-Lakeh M, Morrissey K, Murray K, Nilsson M, Neville T, Oreszczyn T, Owfi F, Pearman O, Pencheon D, Pye S, Rabbaniha M, Robinson E, Rocklöv J, Saxer O, Schütte S, Semenza JC, Shumake-Guillemot J, Steinbach R, Tabatabaei M, Tomei J, Trinanes J, Wheeler N, Wilkinson P, Gong P, Montgomery H, Costello A. The 2018 report of the Lancet Countdown on 
33. Health Canada. Canada's Food Guide. 2019. https://foodguide.canada.ca/en/

centuries to come. Lancet 2018 Dec;392(10163):2479-514. DOI PubMed

24. World Health Organization. Draft WHO global strategy on health, environment and climate change. 2018. http://www. euro.who.int/_data/assets/pdf_file/0003/378903/68id07e_ GlobalStrategyHealthEnvironmentClimateChange_180547. pdf?ua=1

25. Global Center on Adaptation. Global Commission on Adaptation. https://gca.org/global-commission-onadaptation

26. The Lancet Planetary Health. Power to the children. Lancet Planet Health 2019 Mar;3(3):e102. DOI PubMed

27. Youth climate change strikers. Open letter to world leaders. The Guardian March 1, 2019. www.theguardian.com/ environment/2019/mar/01/youth-climate-change-strikersopen-letter-to-world-leaders

28. Stevenson V. Tens of thousands rally in Montreal as part of international "school strike" against climate change. CBC News March 15, 2019. https://www.cbc.ca/news/canada/ montreal/climate-march-montreal-1.5058083

29. Call to Action on Climate Change and Health: from Canada's Health Professionals to Canada's Federal Political Parties. Feb 5, 2019. https://cape.ca/wp-content/uploads/2019/03/PressRelease-CC-Call-to-Action-Feb-5-updated-March-2019.pdf

30. International Federation of Medical Students' Associations. 2020 Vision for Climate-Health in Medical Curricula 2018 (Accessed 2018-10-09). https://docs.google.com/forms/d/e/ 1FAlpQLSeMxig6Yhs4qJU8oboKXm0KqGXRj64fcso8o9lHBik NGX5RYA/viewform

31. Government of Canada. Regulatory Impact Analysis Statement: Regulations Amending the Reduction of Carbon Dioxide Emissions from Coal-fired Generation of Electricity Regulations. Department of the Environment and Department of Health. Feb 17, 2018. http://www.gazette. gc.ca/rp-pr/p1/2018/2018-02-17/html/reg3-eng.html

32. Government of the United Kingdom. Powering Past Coal Alliance: Partners. 2018. https://www.gov.uk/government/ publications/powering-past-coal-alliance-declaration/ powering-past-coal-alliance-partners

34. Willett W, Rockström J, Loken B, Springmann M, Lang T, Vermeulen S, Garnett T, Tilman D, DeClerck F, Wood A, Jonell M, Clark M, Gordon LJ, Fanzo J, Hawkes C, Zurayk R, Rivera JA, De Vries W, Majele Sibanda L, Afshin A, Chaudhary A, Herrero M, Agustina R, Branca F, Lartey A, Fan S, Crona B, Fox E, Bignet V, Troell M, Lindahl T, Singh S, Cornell SE, Srinath Reddy K, Narain S, Nishtar S, Murray CJL. Food in the Anthropocene: the EAT-Lancet Commission on healthy diets from sustainable food systems. Lancet 2019 Feb;393(10170):447-92. DOI PubMed

35. Celis-Morales CA, Lyall DM, Welsh P, Anderson J, Steell L, Guo Y, Maldonado R, Mackay DF, Pell JP, Sattar N, Gill JMR. Association between active commuting and incident cardiovascular disease, cancer, and mortality: prospective cohort study. BMJ 2017 Apr;357:j1456. DOI PubMed

36. City of Vancouver Greenest City Action Plan. https:// vancouver.ca/files/cov/Greenest-city-action-plan.pdf

37. Rees EE, Ng V, Gachon P, Mawudeku A, McKenney D, Pedlar J, Yemshanov D, Parmely J, Knox J. Risk assessment strategies for early detection and prediction of infectious disease outbreaks associated with climate change. Can Commun Dis Rep 2019;45(4):119-26. DOI

38. Ogden $\mathrm{NH}$, Lindsay LR, Ludwig A, Morse AP, Zheng $H$, Zhu $\mathrm{H}$. Weather-based forecasting of mosquito-borne disease outbreaks in Canada. Can Commun Dis Rep 2019;45(5):12732. DOI

39. Kotchi SO, Bouchard C, Ludwig A, Rees EE, Brazeau S. Using Earth observation images to inform risk assessment and mapping of climate change-related infectious diseases. Can Commun Dis Rep 2019;45(5):133-42. DOI

40. Germain G, Simon A, Arsenault J, Baron G, Bouchard C, Chaumont D, El Allaki F, Kimpton A, Lévesque B, Massé A, Mercier M, Ogden NH, Picard I, Ravel A, Rocheleau JP, Soto J. Quebec's Multi-Party Observatory on Zoonoses and Adaptation to Climate Change. Can Commun Dis Rep 2019;45(5):143-8. DOI

41. Ipsos Game Changers. Three Quarters (75\%) Say Canada Needs to Do More to Address Climate Change. https://www. ipsos.com/en-ca/news-polls/three-quarters-75-percent-saycanada-needs-to-do-more-to-address-climate-change 